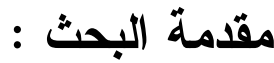

أدي انتشار البث الفضــائي إلــي اتســاع دور وســائل الاتصــال الجماهيري وازدياد وظائفها الإفناعية في المجتمعات المعاصرة خاصة فــي لئي

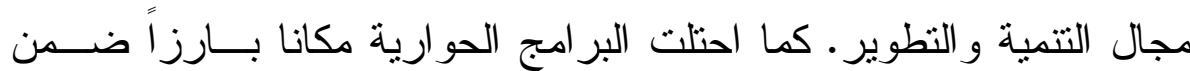

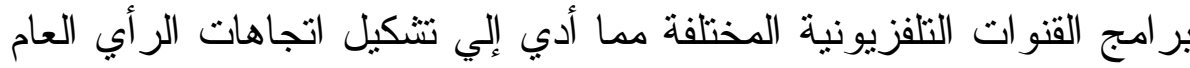
باستخدام البر امج الإعلامية المختلفة، وعادة ما يرتبط محتوي الرسالة التـي لئي

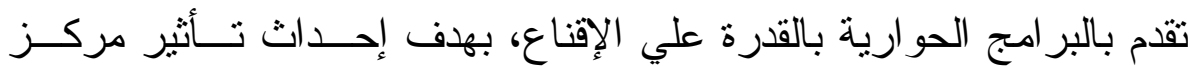

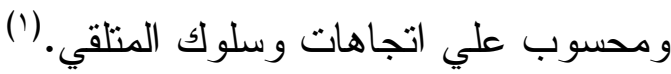

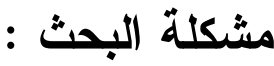

بالر غم من وجود العديد من الدراسـات التي ناقثــــت أوجــهـ عديــــة للبر امج الحو ارية من خلال أهميتها وفاعليتها ودور ها وتأثثير ها علي المتلقي؛

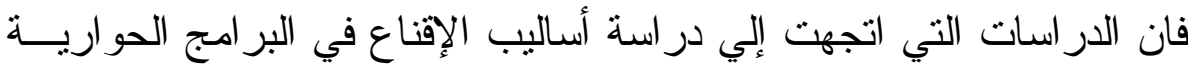

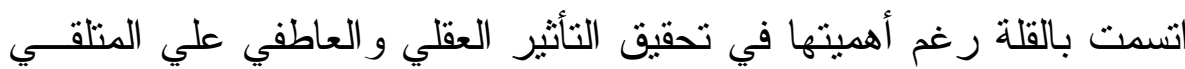

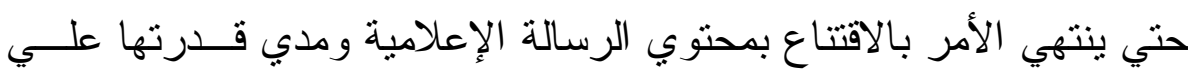
تشكيل اتجاه الر أب العام. ومن هذا المنطلق يهذف هذا البحث إلي التعرف علي دور أسـاليب

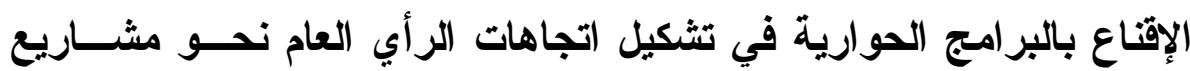

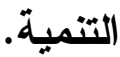
أهمية البحث : 1- تتامي الدور الذي تيؤديه البرامج الحوارية كمصدر للمعلومات عـن

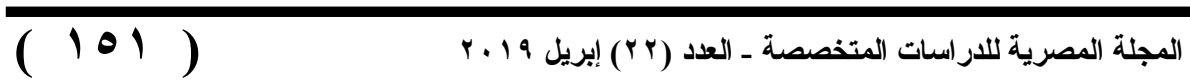


القضايا السياسية و الذي يشكل في النهاية اتجاهات الر أي العام.

r- تعدد الجو انب التي تتاولت أساليب الإقناع كأحد العو امل التي تـــؤثر

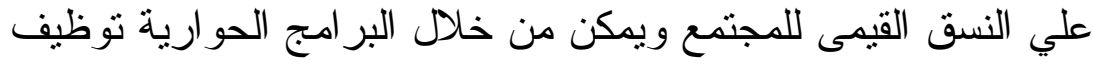
تللك الأساليب النوظيف الأمتلك.

r- قلة الدراسات التي اهتمت بتـأثنير الأســاليب الإقناعيــة بــالبرامج الحوارية في تتكيل اتجاهات الر أي العام نحو مشاريع التنمية.

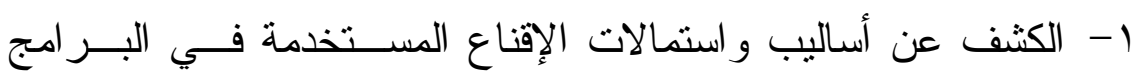
الحوارية لضمان التأثثر علي المتلقي.

r- التعرف علي ددي اقتتناع الجمهور بوجه نظر البــر امج الحواريــة بالقنو ات الفضائية وتقبلهم لها.

r- قياس مدي فاعلية الرسالة الإقناعية في تشكيل اتجاهـات الجمهـور المستهدف تجاه مشاريع التتمية.

ع- الكثف عن مدي تأثثير المتغير ات الوسيطة (مدي مألوفية القضــية-

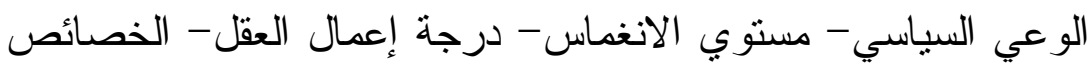

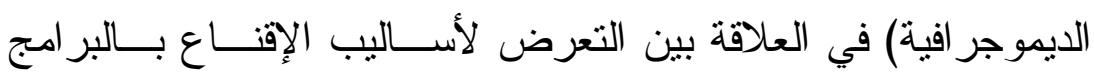
الحو ارية و الاتجاه نحو مشاريع التتمية.

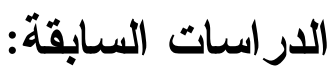
المحور الأول: الدراسات أساليب الإقناع في الخطاب الإعلامي. 


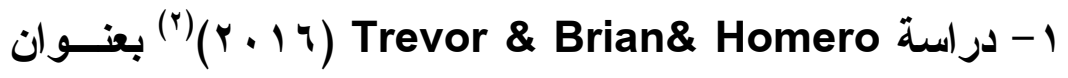
"الإقناع السياسي علي وسائل التو اصل الاجتماعي".

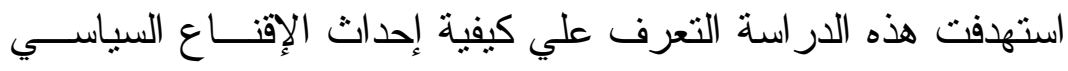

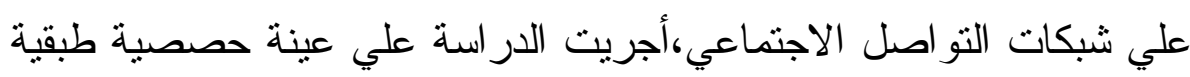
مكونه من . .0 مفردة من مستخدمي شبكات التو اصل الاجتماعي بالو لايات

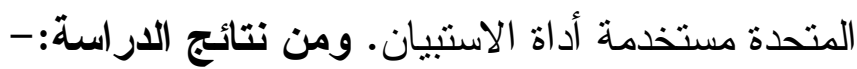
- وجود علاقة ارتباطيه ذات دالة إحصائية بـين التعـرض لوســائل

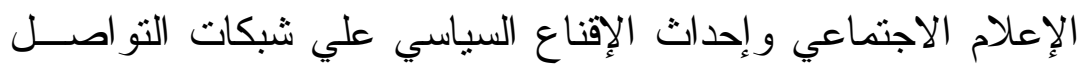

$$
\text { الاجتماعي. }
$$

- مجود علاقة ارتباطيه بين العمر و الدخل والمعرفة السياسية والإقناع

$$
\text { السياسي للإعلام الاجتماعي. }
$$

r ب دراسة ألاء فوزي (10 ب ب) (ץ) بعنوان "الاستر اتيجيات الاتصالية

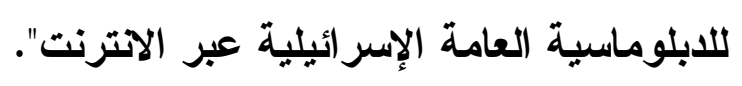

استهفت هذه الدراسة توصيف وتحليل أهم استر اتيجيات و أســاليب الإقناع المستخدمة في صياغة الخطابات الدبلوماســية العامــة الإســــائيلية

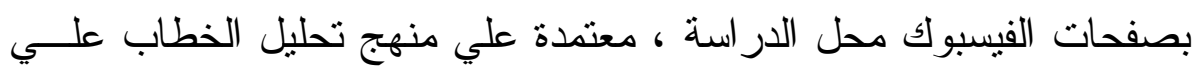

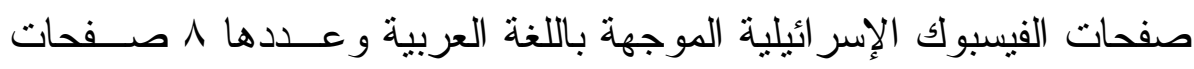

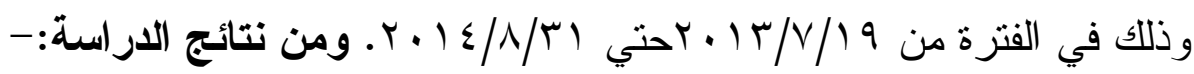
- - أوضحت الدراسة إن إستر اتيجية الإقناع ذات الطابع الدعائي هي أكثر

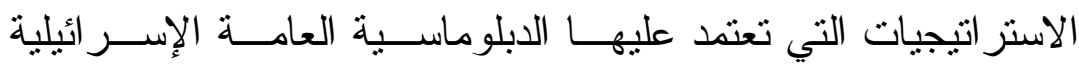

$$
\text { الموجهة لعرب عبر الفيسبوك. }
$$


(ا الثيماء رضا عبره

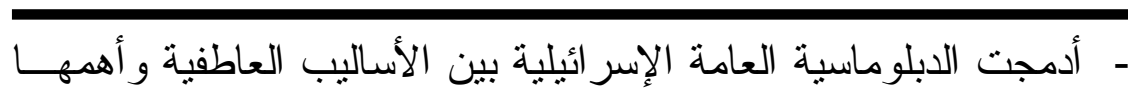
الخوف و التهديد و التكذيب و التشكيك في العدو وبين الأساليب المنطقية خاصة تقديم البرهنة في إطار إثبات صحة ما تقوله إسر ائيل.

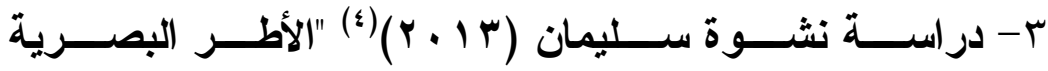
واستر اتيجيات الإقناع في المناظرات والأحاديــث التلفزيونيـة لمرشـــي

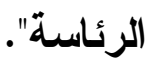

استهدفت هذه الدر اسة التعرف علي استر اتيجيات الإقناع التي تبناها

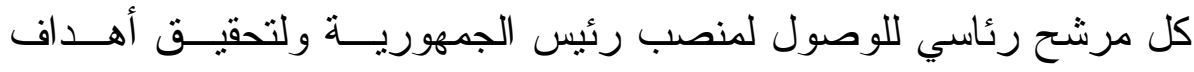
الدر اسة اعتمدت الباحثة علي منهج تحليل الخطاب لبرنامج (مصر تتنخــب الرئيس)، بالإضـافة إلي المناظرة الرئاسية الوحيدة التي أجريت بين كل مسن

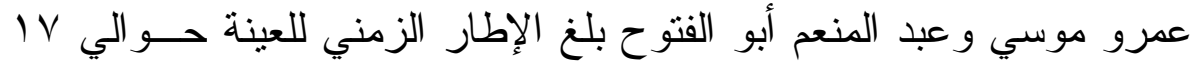
ساعة تلفزيونية مستخدمه أداة تحليل المضمون. ومن نتائج الدراسة:- المناظرة الرئاسية ركزت في معظمها علــي الإطـــار الاســتر اتيجي الهجومي بنسبة أكبر من جانب المرشح أبو الفتوح.

- ركز المرشح أحمد شفيق في حديثة علــي مفهــوم الخبــرة و الإدارة و القدرة علي السيطرة علي الأمور لجـــب ناخبيــهـ مـــن ينـادون بالاستقر ار بعد مرحلة من التونز السياسي.

المحور الثاني:الار اسات المتعلقة بوسائل الإعلام وتثكيل الاتحاهات

السباسبية

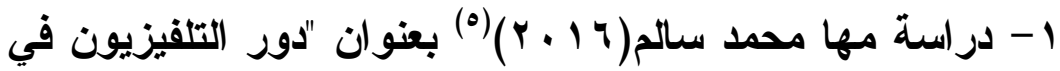

تثكيل اتجاهات الجمهور المصري نحو ثقافة الاحتجاج والتظاهر".

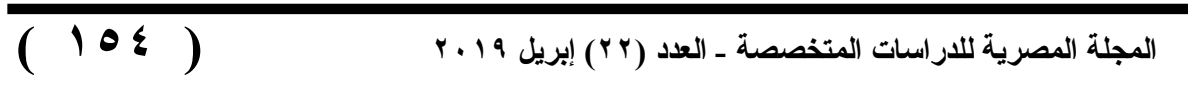


استهـفت هذه الدراسة التعــرف علــي دور القنـــوات التليفزيونيـــة

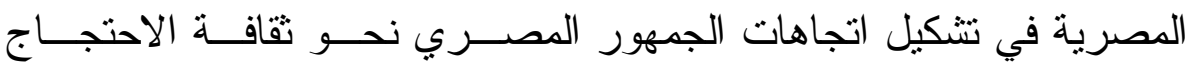
و التظاهر، ولتحقيق أهداف الدر اسة اعتمدت الباحثة علي منهج المسح بالعينة

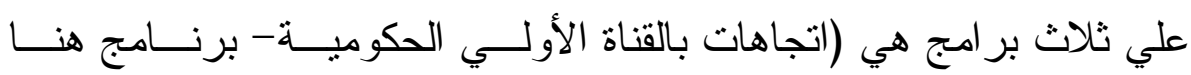

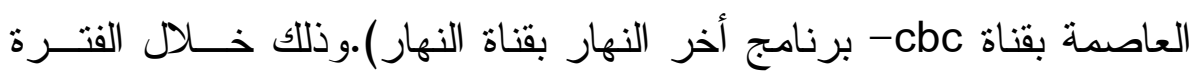

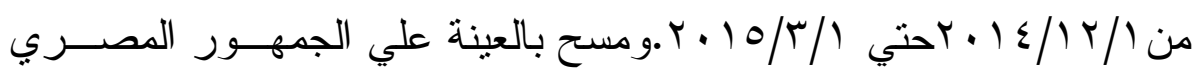

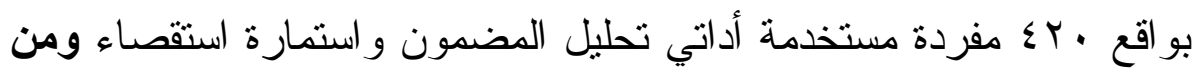

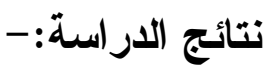

- تفوق أسلوب الجمع بين الاستمالات العاطفية و المنطقية المستخدمة في

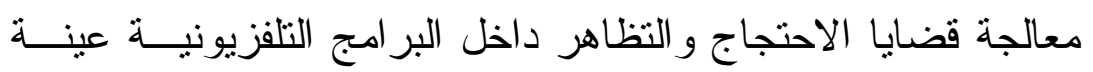

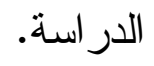

- تغطية البرامج التلفزيونية الحكومية الخاصة هي وراء ازدياد نسـبة

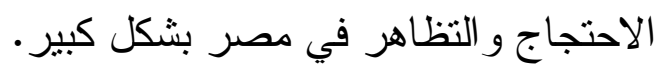

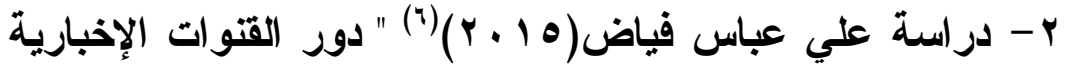
في تثكيل اتجاهات الرأي العام نحو القضايا السياسية العر اقية".

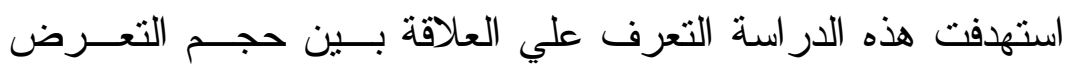
للقنوات الإخبارية العربية واتجاهات الجمهور العراقي نحو القضايا السياسية

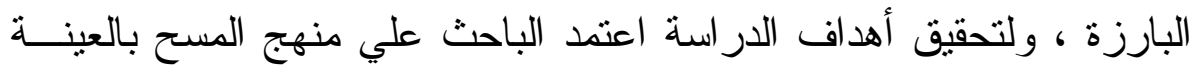

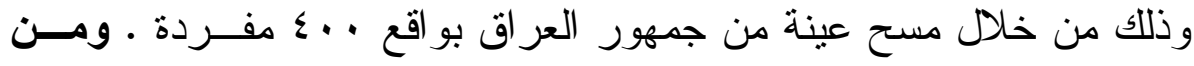
نتائج الاراسة:- من خلأ 
(ا الثيماء رضا عبره

- توجد علاقة ارتباطيه بين حجم التعرض للقنو ات الفضائية و الاتجـــاه

نحو القضايا السياسية العر اقية .

- يؤثز مستوي الاهتمام السياسي علي العلاقة بـين حجــم التعـرض

للقنو ات الإخبارية واتجاهات الجمهور نحو القضايا السياسـية محــل

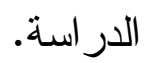

- يؤثر مستوي المعرفة السياسي علي العلاقة بـين حجــم التعـرض

للقنو ات الإخبارية واتجاهات الجمهور نحو القضـايا السياسـبـة محــل

الدر اسة

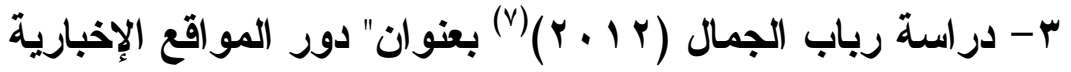

الاككترونية في تثكيل معارف واتجاهات المغتربين المصريين نحو الأحداث

السياسية في مصر".

استهدفت هذه الدر اســة التعـرف علـي دور المواقــع الإخباريــة

الالكترونية في تشكيل معارف و اتجاهات المغتربين نحو الأحداث السياســية

في مصر لفترة ما بعد ثورة مب يناير ، تتتمي هذه الدر اسة إلي الدراســات

الوصفية معتمدة علي منهج المسح باستخدام أداة الاستبيان. حيث أجريــــ

الدر اسة الميدانية علي عينة قو امها . 9 مفردة من 7 مدن ســعودية ممثلـــة

للمملكة المتحدة بو اقع ، 10 مفردة من كل مدينة. ومن نتائج الار اسةة:-

- لم يثبت وجود علاقة دالة إحصائيا بين طبيعة الاتجاه الذي يتكون لدي

عينة البحث وبين مستوي الاهتمام بالأحداث السياسية في مصر بعـــ

$$
\text { الثورة. }
$$

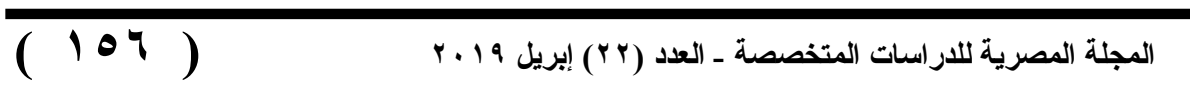


- - حققت المو اقع الإخبارية لكل من الذكور و الإناث مســتوي معرفيــا بسبب المجال الذي أحدثه هذه المو اقع لكلا الجنسين لمتابعة ومناقتشة

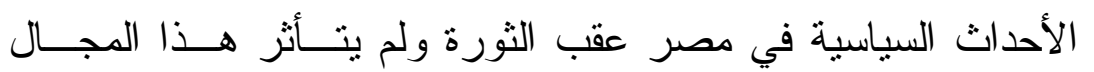

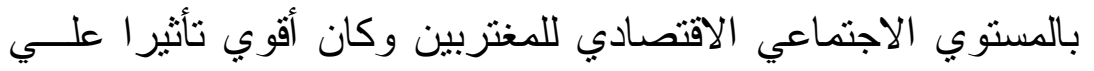

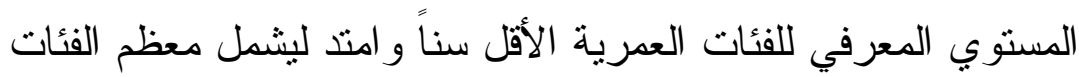
التعليمية ويثبت بذلك قوة تأثير ذلك المجال علي المعرفة لدي فئسات

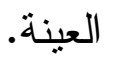

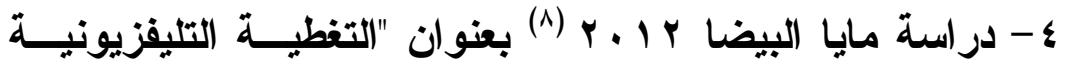

للقضايا اللبنانية السياسية وعلاقتها باتجاهات الرأي العام اللبناني نحوها". استهدفت هذه الدراسة رصد وتحليل التغطية الخبرية في نثــرات الأخبار و البر امج الإخبارية المقدمة في القنوات الفضائية اللبنانية "المنــار

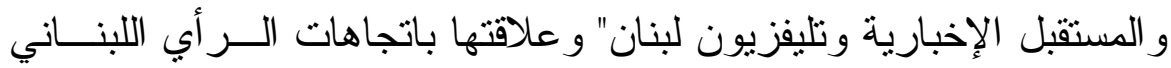

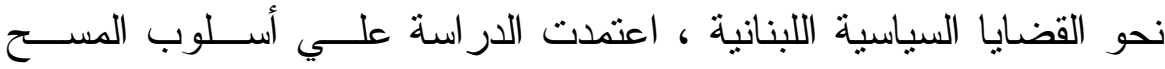

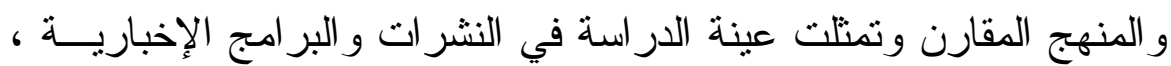

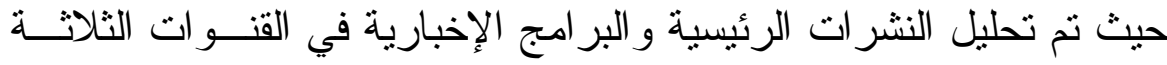

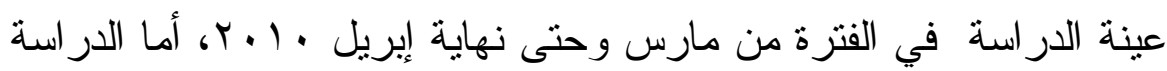

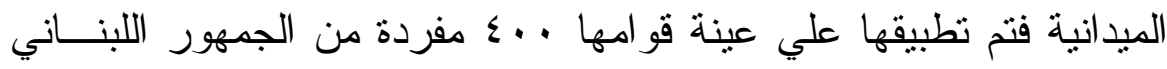
العام موزعة بالتساوي ـ ومن نتائج الدراسة:- - رفض الفرض القائل بوجود علاقة ارتباطيه دالة إحصائيا بين دوافع

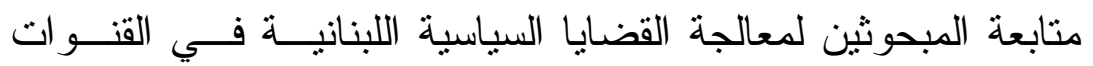
الفضائية اللبنانية وبين اتجاهات المبحوثين نحو هذه القضايا. 
r- ما مدي انتباه المبحوثين لمحتوي الرسالة الإقناعية بالبر امج الحوارية

$$
\text { في معالجة مشاريع التتمية؟ مانج }
$$

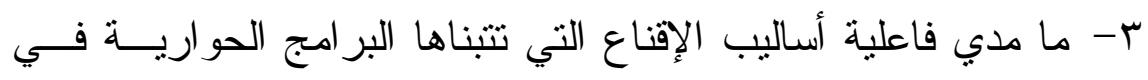

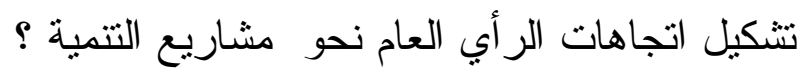

ـ - ما مدي اقتتاع الجمهور بوجه نظر البـــرامج الحواريــة بــالقنوات

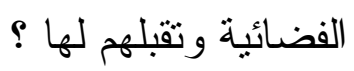

0- ما مدي تأثثر المتغير ات الوسيطة (مدي مألوفية القضـــية- الــوعي

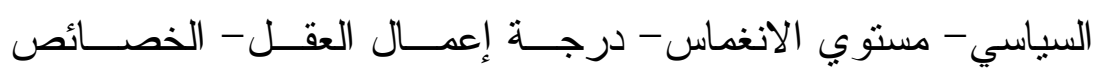

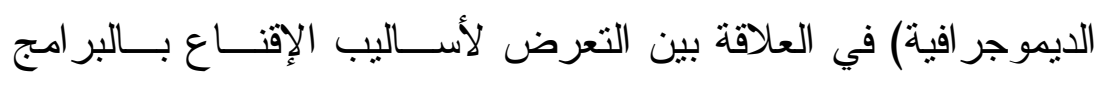
الحو ارية و الاتجاه نحو مشاريع التتمية.

\section{فروض الدراسة}

الفرض الأول : توجد علاقة ارتباطيه بين حجم التعرض لأساليب الإقتــاع بالبر امج الحوارية وشدة الاتجاه الايجابي نحو مشاريع التتمية.

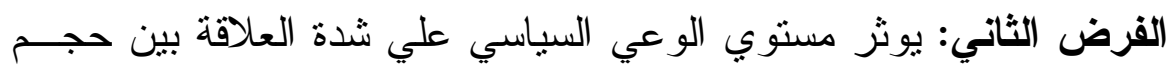

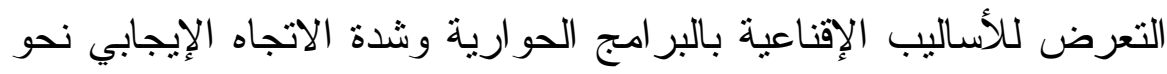
مشاريع التتمية. الفرض الثالث: يوثر مستوي مألوفية القضية علي شدة العلاقة بين حجـ

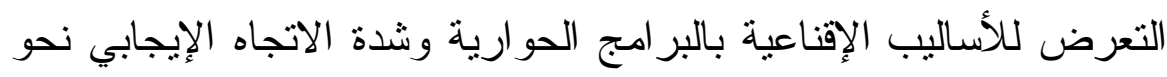
مشاريع التنمية. 
(ا الثيماء رضا حبره

الفرض الر ابع: يؤثر مستوي الانغماس علي شدة العلاقة بين حجم التعرض للأساليب الإقناعية بالبر امج الحوارية وشدة الاتجاه الإيجابي نحو مشــاريع

التنمية.

الفرض الخامس: تؤثر درجة إعمال العقل علي شدة العلاقـــة بــين حجــم التعرض للأساليب الإقناعية بالبر امج الحوارية وشدة الاتجاه الإيجابي نحو مشاريع التتمية.

الفرض السادس: تؤثر المتغير ات الديموجر افية للمبحوثين علي شدة العلاقة بين حجم التعرض للأساليب الإقناعية بالبر امج الحوارية وشــدة الاتجـــاه الإيجابي نحو القضية محل الدر اسة وذلك علي النحو التالي:أ- يؤثز التعليم علي العلاقة بين حجـــم التعــرض للأســاليب الإقناعيــة بالبر امج الحوارية وشدة الاتجاه الإيجابي نحو مشناريع التتمية. ب- يؤثز السن علي العلاقة بين حجم التعــرض للأســاليب الإقناعيــة بالبر امج الحوارية وشدة الاتجاه الإيجابي نحو مشاريع التتمية. ج- يؤثر النوع علي شدة العلاقة بين حجم التعرض للأساليب الإقناعيــة بالبر امج الحوارية وشدة الاتجاه الإيجابي نحو مشاريع التتمية.

نوع الدر اسة ومنهجها :

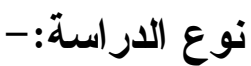

تتتمي هذه الدر اسة إلى الدر اسـات الوصفية حيث تســتهدف هــذه الدر اسة در اسة مدي قدرة أساليب الإقناع علي تشكيل اتجاهات الر أي العام نحو مشاريع التتمية، و استكثاف العلاقات بين المتغير ات المختلفــة حيـــث تدرس العلاقة بين حجم التعرض للأسـاليب الإقناعية بــالبر امج الحواريـــة

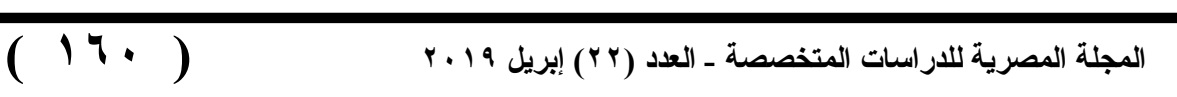


الذي تتاول القضية محل التطبيق من ناحية والاتجاه نحو هذه القضية مـن

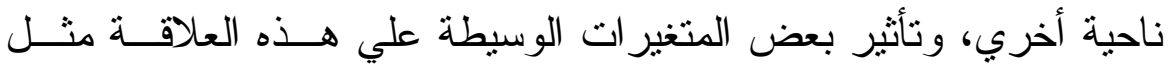
مستوي الانغماس في القضية، ومستوي الوعي السياسي، وبعض المتغير ات التيريز الديموجر افية مثل: التعليم و السن و النوع.

$$
\text { منهج البحث:- - - من }
$$

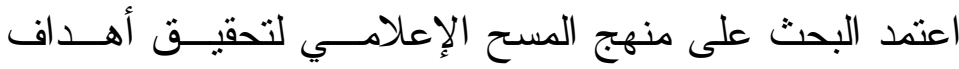

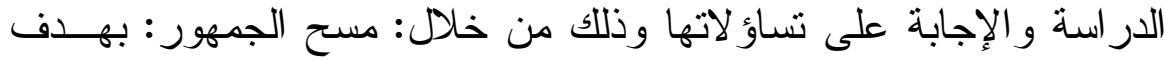

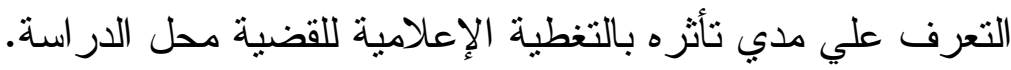

مجتمع البحث: تمثل مجتمع البحث في ســكان مدينــة القـاهرة

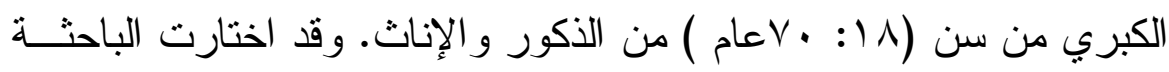

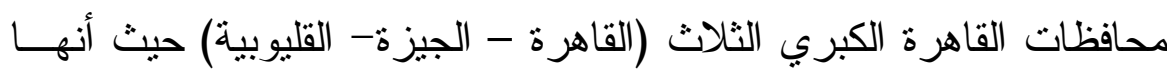
تحتل المقدمة بين محافظات الجمهورية من حيث الكثافة السكانية وكـــلك الك الكرة تتوع أحيائها في مستوياتها الاجتماعية و الاقتصادية بما يسمح بتمثيل هــــه الخصائص في عينة الدر اسة.

عينة الار اسة: عينة عشو ائية بسيطة قوامهــــ . . عمفــردة مــن الجمهور المصري للإجابة علي أسئلة استمارة الاستنيان

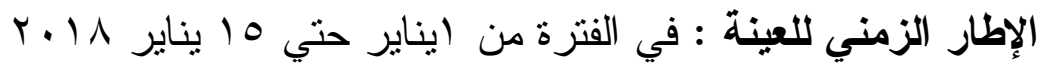

$$
\text { أدوات جمع البيانات:- }
$$

أداة الاستبيان : تعتمد هذه الدراســة علـى أداة الاسـتبيان فــي

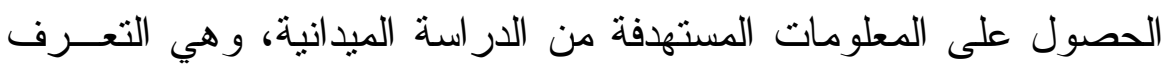


(الثيماء رضا حبره

على مدي تأثير الأساليب الإقناعية المستخدمة في البر امج الحوارية علــي تكوين رأى العام نحو مشاريع التتمية.

\section{اختبـر صدق وثبات الاستمارة:--}

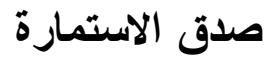

صدق المحتوي : حيث تم تحديد أهــــاف الدراســـة وتشــاؤلاتها وترجمه ذللك في شكل فروض بعد الإطلاع على التــراث العلمــي علـي

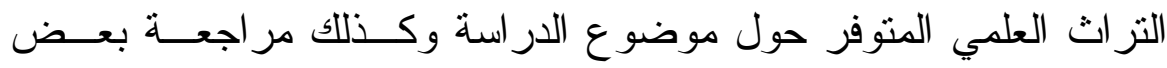
الدر اسات السابقة ثم وضع الأسئلة التي تغطي أهداف وتساؤلات الدر اسة. الصدق الظاهري: وتم التحقق من الصدق الظاهري مــن خــلال عرض صحيفة الاستبيان مع توضيح أهدافها وتساؤ لاتها على مجموعة من من المحكمين من المتخصصين في الدراسات الإعلامية و السياسـية و النفســية وبلغت نسبة اتفاقهم ب9\%، وبناءً على ما أبداه المحكمون من ملاحظات تم إجر اء التعديلات التي أوصو ا بها على أسئلة الصحيفة.

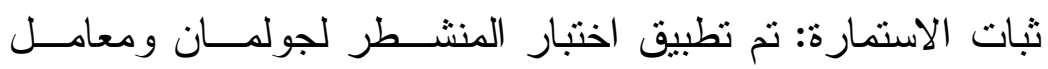
الارتباط ALPHA علي بعض المقاييس في الاستمارة منل مقياس الاتجــاه نحو القضية و المقاييس الخاصة بالسمات الثخصية. جدول رقم (1) م الخاصة بمقاييس الدر اسة

\begin{tabular}{|c|c|}
\hline alpha معامل & المقياس \\
\hline •, & الاتجاه نحو مشاريع التتمية \\
\hline.,$\vee 07$ & الميل للجدال \\
\hline$\cdot, \vee \vee 99$ & الحاجة للمعرفة \\
\hline$\cdot, 970$ & السلطوية \\
\hline
\end{tabular}


وبشكل عام نجد أن جميع قيم المعاملات بالجـدول الســابق

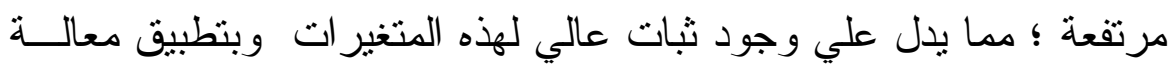

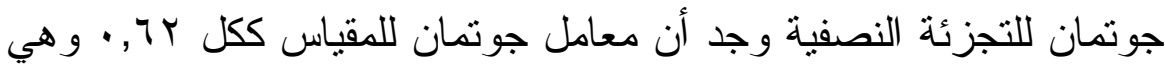
قيمة ثبات مرتفعة في المقاييس ويمكن الاعتماد عليها. الأساليب الإحصائية المستخدمة في الاراسة:-

تم استخدام الاختبارات الإحصائية التالية : 1- النكر ارات البسيطة و النسب المئوية . r- المتوسطات الحسابية و الانحر افات المعيارية . ب- كاب لجداول النو افق - معامل النو افق

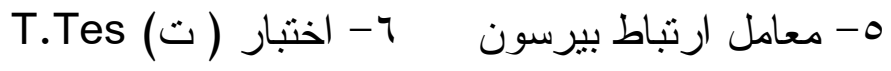

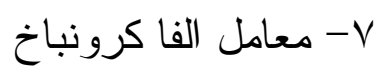
مفاهيم البحث:

الإقتاع(·') هو عملية اتصالية تراكمية تعتمد علي جهـود منتاليــة

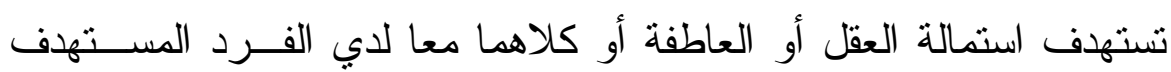

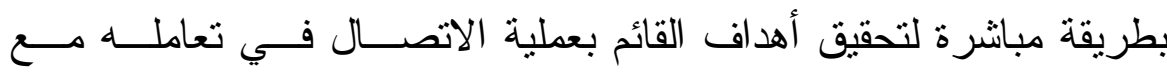

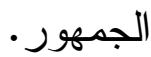

أساليب الإقناع: يمكن تعريف الأساليب الإقناعية إجر ائيا بأنها تلك

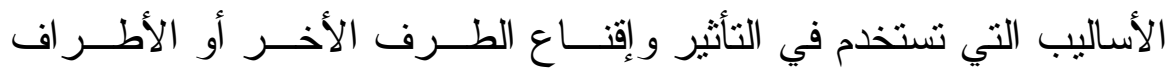

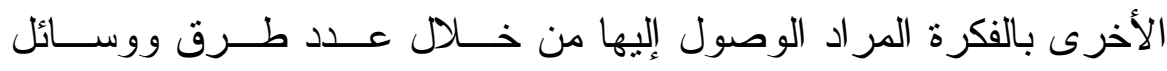

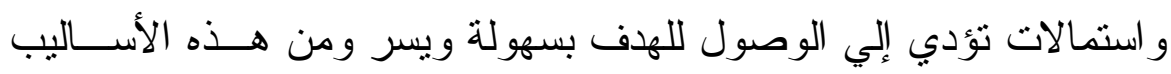


(ا الثيماء رضا حبره

تقديم الرسالة لأدلة وشو اهد و عرض جانب و احد مــن الموضـــوع مقابـلـل عرض الجانبين المؤيد و المعارض و التكرار و التدعيم ووضوح الأهــداف

$$
\text { و غير ها من الأساليب الأخرى }
$$

البرامج الحوارية :(1') هي احد أنواع الفنون الإعلامية التليفزيونية وتثوم علي فكرة البرنامج علي الحوار أما باستضافة شخصية معينــة ذات علاقة مباشرة بموضوع الحوار، أو عن طريق الاتصال لمعرفة رأيها حول القضية المطروحة للنقاش.

تشكيل الاتجاهات(ז') هو نسق أو تتظيم لمشاعر الثخص ومعارفه وسلوكه، أو استعداده للقيام بأفعال معينة ويتمنل في درجات من القبــول أو

$$
\text { الرفض لموضو عات الاتجاه. }
$$

ولأهداف الدراسة يعرف تشكيل الاتجاه إجر ائيا بأنه: وجهة النظر أو الموقف الذي يتبناه الفرد إزاء قضية تههه. وهي هنا تشكيل اتجاهــات الر أي العام نحو مشاريع التتمية في مصر •

\section{تـتائج الار (سـة :}

1 - معدلات تعرض المبحوثين للبرامج الحوارية بالقتوات الفضائية

- - جاء ترنيب معدلات مشاهدة المبحوثين للبر امج الحواريــة بــالقنو ات الفضائية كالأتي: احتل المبحوثون الذين يثاهدونها بمعدل مرتفع في

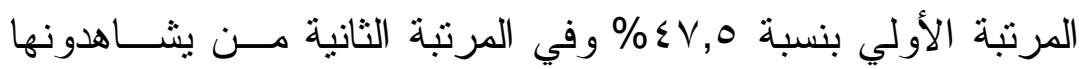
بمعدل متوسط بنسبة rr,V و واحتل من يشاهدونها بمعدل منخفض

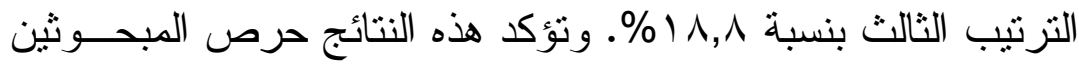
عينة الدر اسة علي مشاهدة البر امج الحوارية المقدمة فــي القنــوات

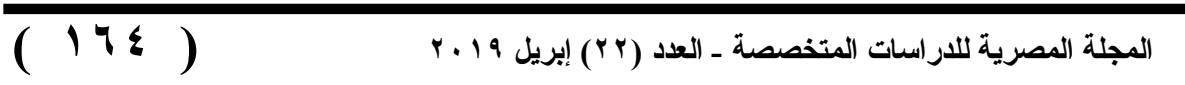


الفضائية ومتابعة التغطية الخاصة بمشروعات التتمية الدقامسـة فـي مصر بهذه القنوات، و أكثر تعرضا لأساليب الإقتاع المستخدمة فـي لئي تغطية هذه المشاريع بالبر امج الحوارية.

ץ- مدي انتباه الجمهور لمحتوي الرســالة المتعقــة بمشــاريع التنمية بالبرامج الحوارية.

- أسلوب مشاهدة المبحوثين لمضمون الرسالة الإقتاعية لمشاريع التتمية

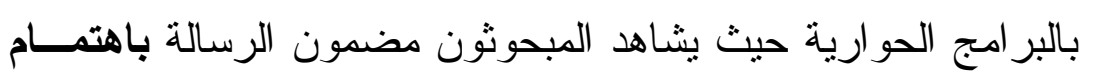

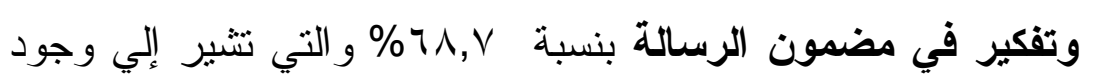

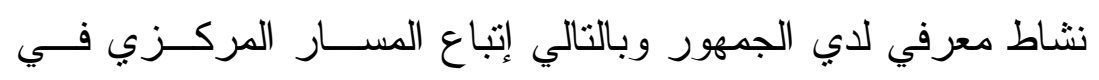

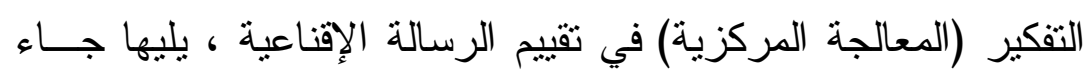

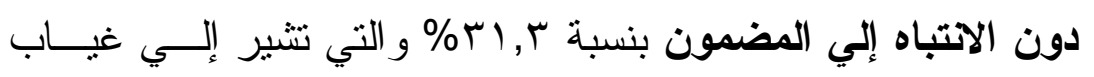

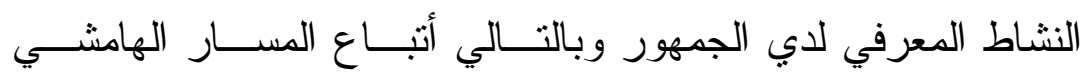

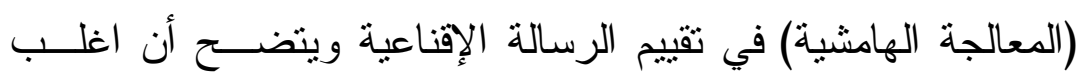

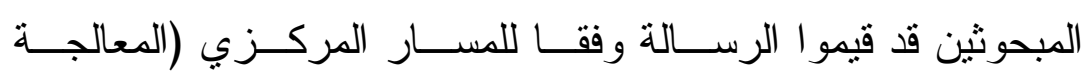

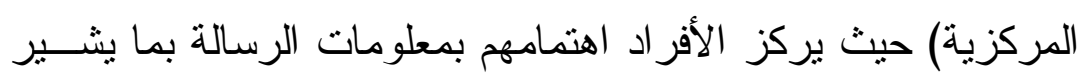

$$
\text { إلي أن درجة إقناعهم كانت قوية. }
$$

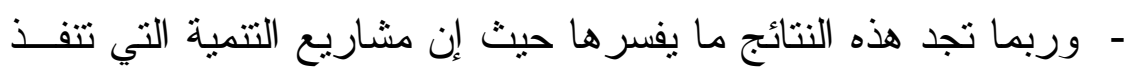

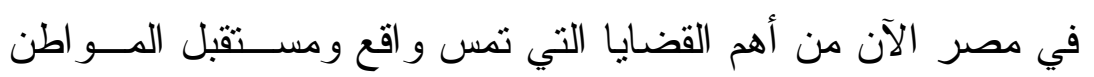

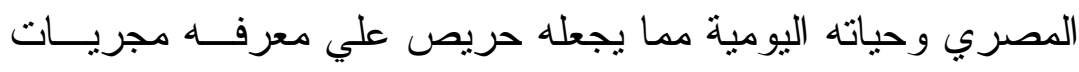
الأحداث ومدي تأثثر ها علي حياته ومستقبله. 
(ا الثيماء رضا عبره

r- مبررات الاثتناع بوجهة نظر البرامج الحوارية فيمس يخـص رضص

مشاريع التنمية.

- جاء المبرر الخاص بالطريقة المركزية في تثكيل الاتجاهات "قــوة

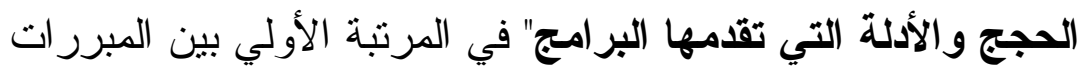

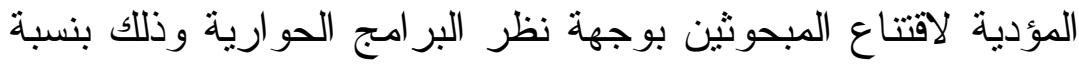

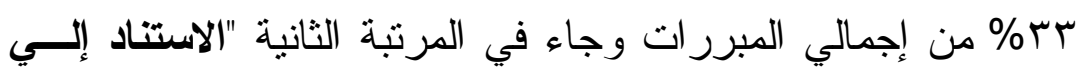

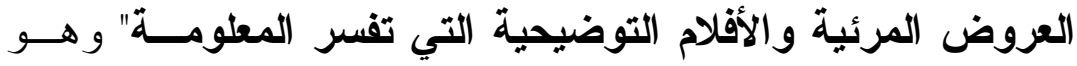

أيضا من المبررات المتعلقة بالطريقة المركزية في تثكيل الاتجاهات

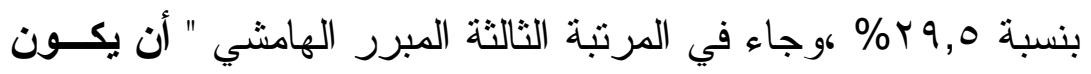

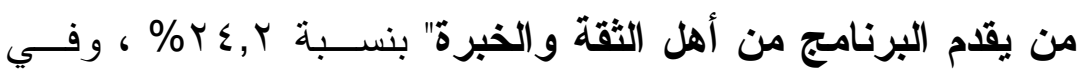

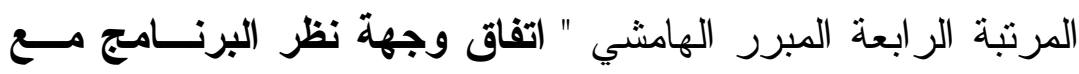

وجهة نظر غالبية أفراد المجتمع".

- وتؤكد هذه النتائج أن أفر اد العينة يدققون في المعلومــات و الأفكـار المتعلقة بمشاريع التتمية التي يتعرضون لها ويحاولون الوقوف علي

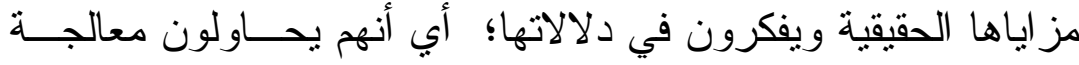

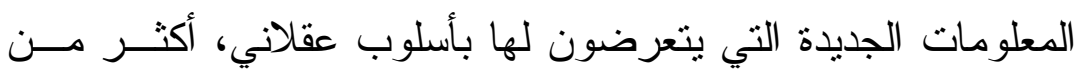

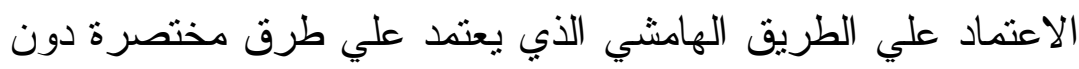

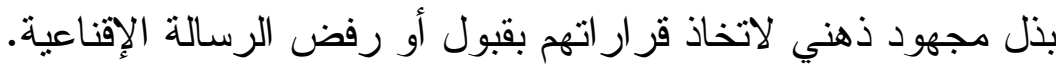
ع -تأثير تكرار أو كثافة انتثار الرسالة الإقناعية علي المبحوثين - ـ أن أكثر من نصف عينة الدراسة تري أن تكرار الرســالة الإقتاعيــة

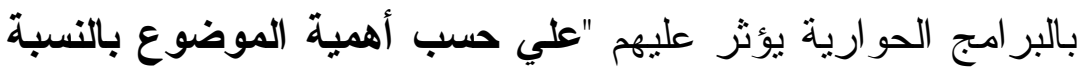

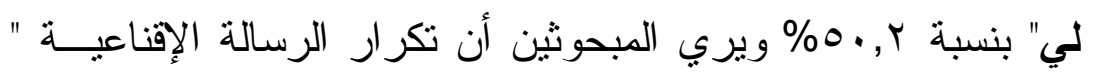

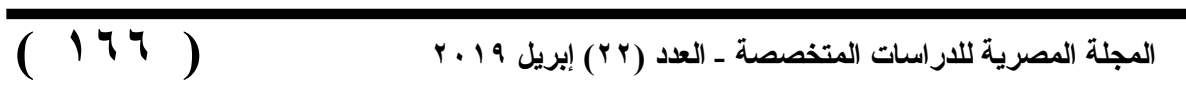




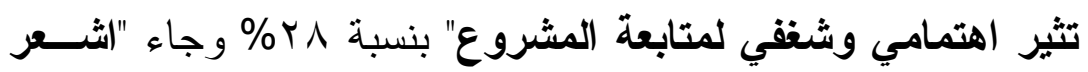

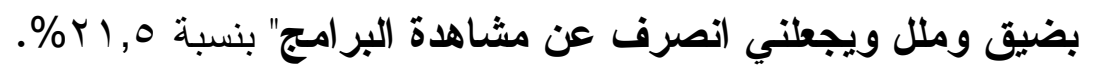

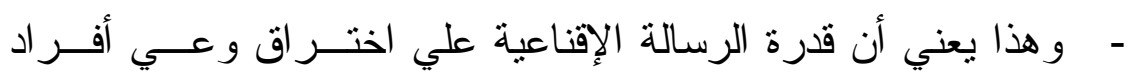

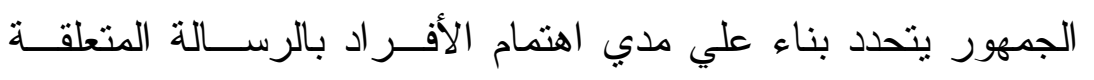

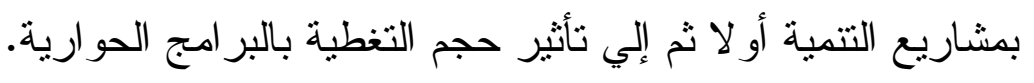
ه- مدي تأثير أساليب الإقتاع بالبرامج الحوارية في تغيير اتجاهات الجمهور المستهدف تجاه مشاريع التنمية . - أن نسبة rov, rov من إجمالي عينة الدر اسة يغيرون رأيهم إذا أقنعتهم

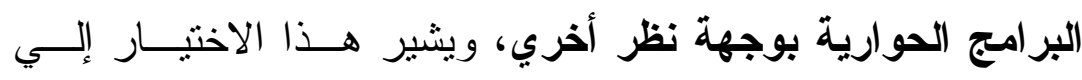

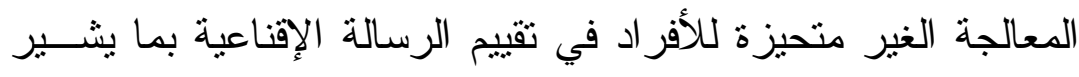

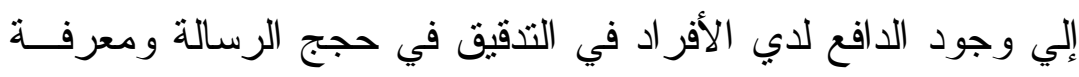

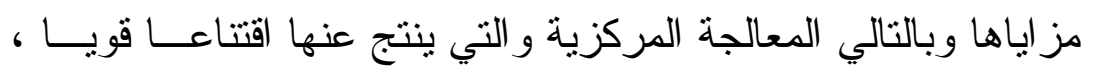

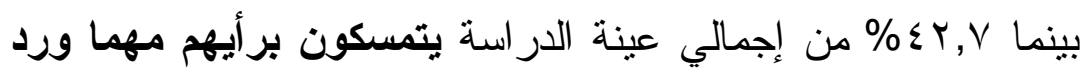

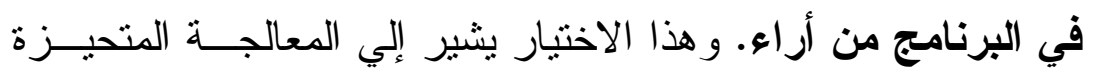

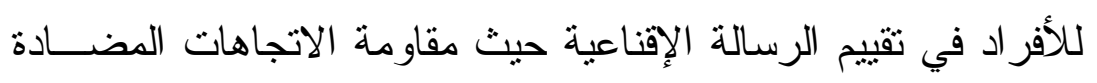

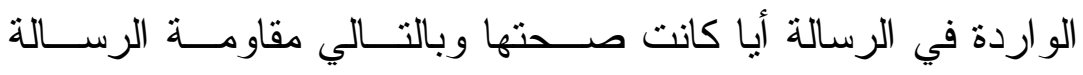
ورفضها. و هذا يشير إلي قدره أساليب الإقناع التي يتم استخدامها في

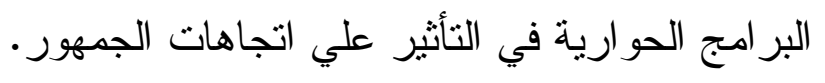

ثالثا: نتائج اختبار ات فروض الدراسة الميدانية - هنالك فروق دالة إحصائيا بين منوسطات شدة الاتجاه الايجابي نحسو

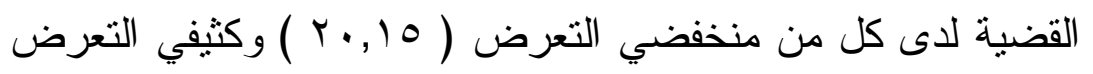


(ا الشيماء رضا عبره

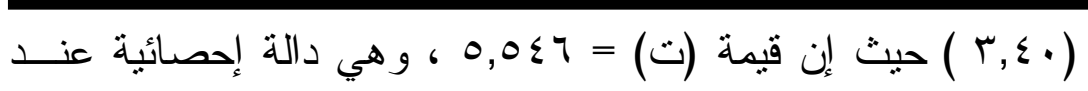

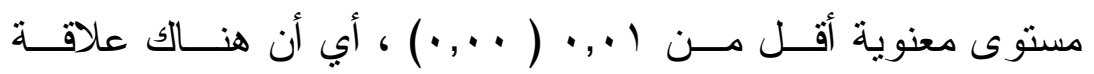

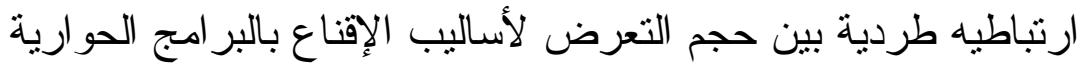
وشدة الاتجاه نحو القضية .ومن ثم نقبل الفرض الأول" توجد علاقة

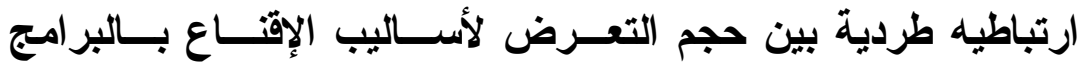
الحوارية وشدة الاتجاه الايجابي نحو القضية محل الدراسة". - وجود فروق دالة إحصائية بين منوسطات شدة الاتجاه لدى كل مسن

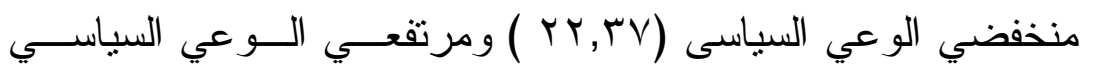

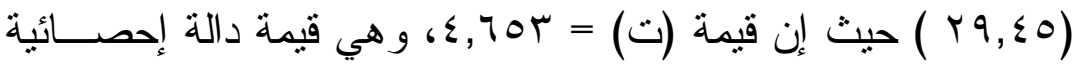

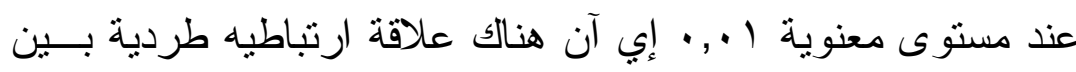

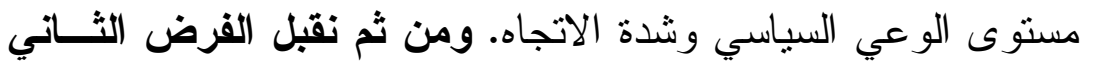
"يوثر مستوي الوعي العياسي علي شدة العلاقة بين حجم التعرض

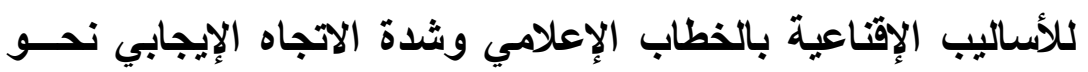

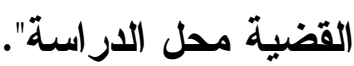
- وجود فروق دالة إحصائية بين منوسطات شدة الاتجاه لدى كل مـن

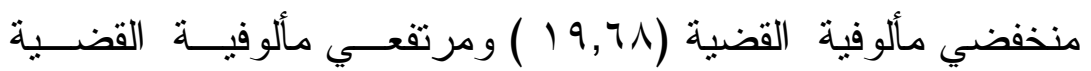

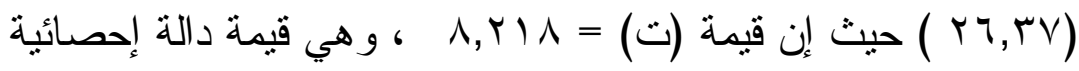

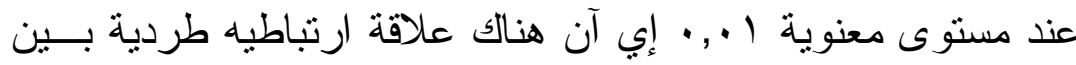

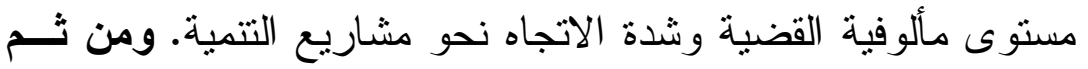
نقبل الفرض الثالث "يوثر مستوي مألوفية القضية علي شدة العلاقة

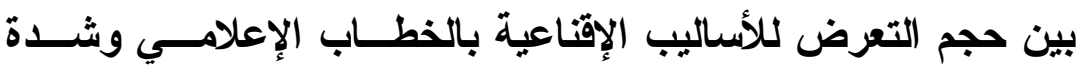
الاتجاه الإيجابي نحو القضية محل الدراسة". 
- وجود فروق دالة إحصائية بين منوسطات شدة الاتجاه لدى كل مسن

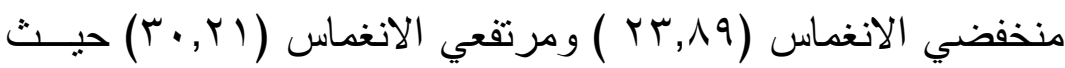

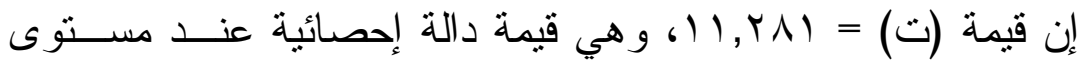

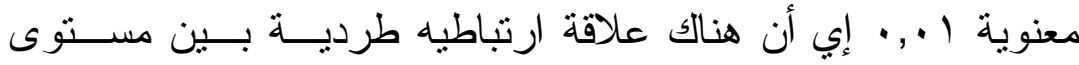

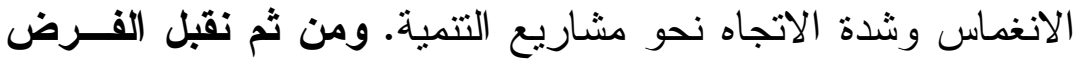

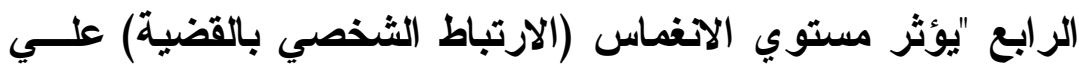

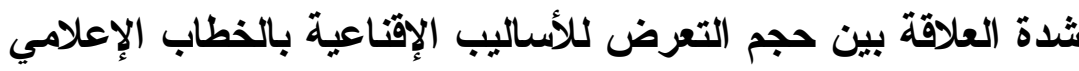
وشدة الاتجاه الإيجابي نحو القضية محل الاراسة". - وجود فروق دالة إحصائية بين منوسطات شدة الاتجاه لدى كل مسن منخفضي درجة إعمال العقل (Y (Y,Y, ومرتفعي درجة إعمال العقل

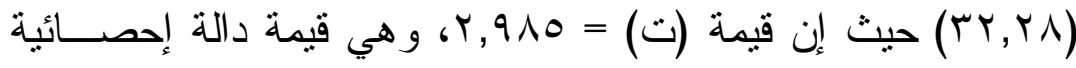

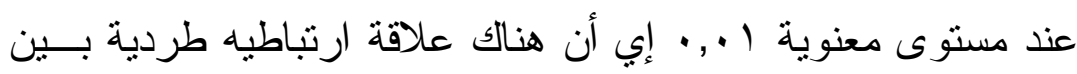

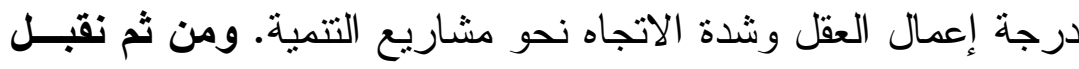

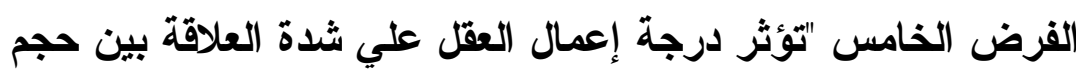

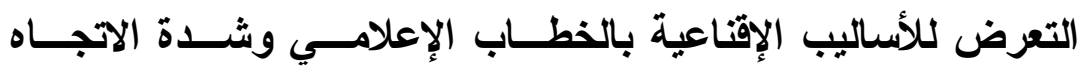
الإيجابي نحو القضية محل الاراسة". - عدم وجود فروق دالة إحصائية بين متوسطات شدة الاتجاه لدى كـلـ

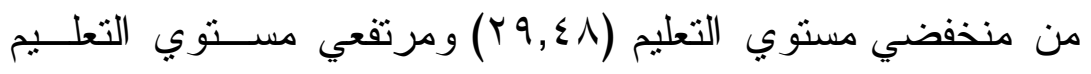

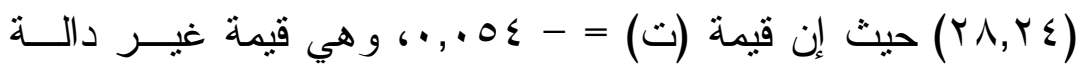
إحصائيا عند مستوى معنوية ال, إن. - إي أنه لا يوجد علاقة ارتباطيه طردية بين مستوي التعلـيم وشـــدة

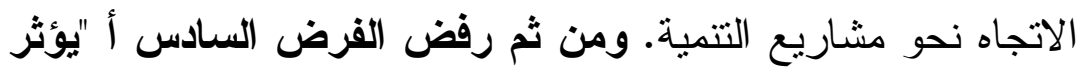


(ار الشيماء رضا حبره

مستوي التعليم علي شدة العلاقة بـين حجــم التعـرض للأســاليب الإقناعية بالخطاب الإعلامي وشدة الاتجاه الإيجابي نحـو القضــية

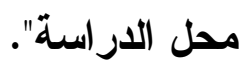

- عدم وجود فروق دالة إحصائية بين منوسطات شدة الاتجاه لدى كـلـ

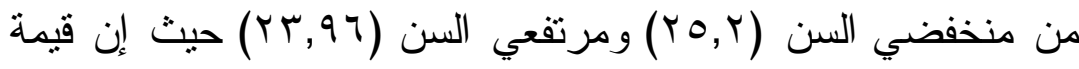

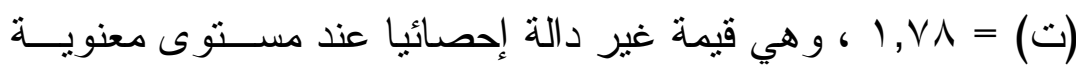
1 نحو مشاريع التتمية. ومن ثم رفض الفرض السادس ب "يؤثر السن علي شدة العلاقة بين حجم التعرض للأسـاليب الإقتاعيــة بالخطــاب الإعلامي وشدة الاتجاه الإيجابي نحو القضية محل الاراسة". - عدم وجود فروق دالة إحصائية بين متوسطات شدة الاتجاه لدى كــل

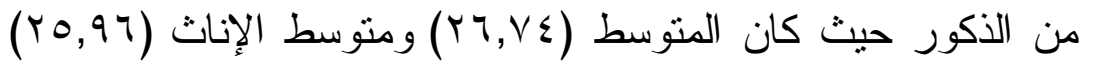

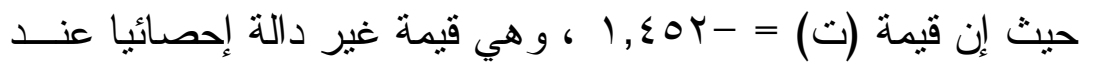
مستوى معنوية ا +, , إي أنه لا يوجد علاقة ارتباطيه طرديــة بـين

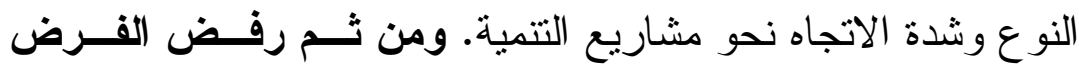

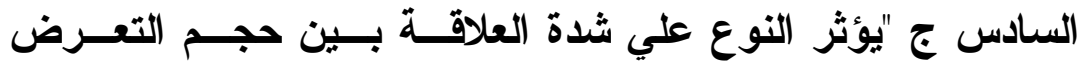
للأساليب الإقتاعية بالخطاب الإعلامي وشدة الاتجاه الإيجابي نـــو القضية محل الار اسة". 
دور أساليب الإقتاع بالبر امج الحوارية فى تثكيل اتجاهات الرأى العام نحو مشروعات التنمية

\section{جدول رقم (ץ)}

توزيع المبحوثين وفقا لمعدلات مشاهدته البرامج الحوارية بالقتوات الفضائية

\begin{tabular}{|c|c|c|}
\hline$\%$ & ك5 & حجم التعرض \\
\hline $1 \wedge, \wedge$ & vo & منخفض \\
\hline Tr,V & $11 \%$ & متوسط \\
\hline$\sum \vee, 0$ & 19. & مرتفع \\
\hline $1 \ldots$ & $\varepsilon \ldots$ & المجموع \\
\hline
\end{tabular}

جدول رقم (r) (ب)

توزيع عينة الار اسة وفقا لارجة الاتتباه لمحتوي البرامج الحوارية التي تناقش

مشروعات التنمية

\begin{tabular}{|c|c|c|}
\hline النسبة & العدد & درجة الاتتباه \\
\hline TI, ro & ITO & تشاهدها دون الانتباه إلي مضمونها \\
\hline$\uparrow \wedge, \vee 0$ & rVo & تشناهدها باهتمام وتفكر في مضمونها \\
\hline $1 \cdots$ & $\varepsilon \ldots$ & المجموع \\
\hline
\end{tabular}

جدول رقم (؛) - (؟)

توزيع استجابات عينة الدراسة لمبررات الاقتناع بوجهة نظر البرامج الحوارية فيما يخص مشاريع التنمية.

\begin{tabular}{|c|c|c|}
\hline النسبةة & 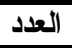 & مبررات الاقتناع \\
\hline Y),0. & $\wedge 7$ & اتفاق وجهة نظر البرنامج مع وجهة نظر غالبية أفر اد المجتمع. \\
\hline rr,.. & irt & قوة الحجج و الأدلة التي تقدمها البر امج. \\
\hline 10,10 & Tra & إن تقدم البر امج عدد كبير من الحجج و البر اهين. \\
\hline$r \leqslant, Y_{0}$ & 97 & إن يكون من يقدم وجهة النظر هذه من أهل الثقة والخبرة. \\
\hline IY,VO & 01 & اتفاق وجهة نظر البرنامج مع وجهة نظري الشخصية . \\
\hline $7, Y_{0}$ & ro & حبي الثخصي لمن يقدم وجهة النظر هذه. \\
\hline$V, Y_{O}$ & rq & تكر ار المعلومات الهامة في الرسالة. \\
\hline Y৭,0. & 111 & الاسنتاد إلي العروض المرئية و الأفلام التوضيحية لتفسر المعلومات. \\
\hline$r, 0$. & 1. & الاستتاد إلي أساليب التخويف و إثارة المشاعر . \\
\hline$\cdot, 0$ & r & أخر تي تذكر \\
\hline \multicolumn{2}{|c|}{$\varepsilon$} & جملة من سئلوا \\
\hline
\end{tabular}


(ا (الثيماء رضا حبره

جدول رقم) (0) - (0)

توزيع عينة الدراسة وفقا لمدي تأثثر تكرار الرسالة الإقناعية بالبرامج الحوارية

\begin{tabular}{|c|c|c|}
\hline النسبة & 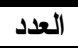 & 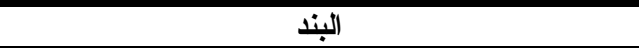 \\
\hline r人 & 114 & تثير اهتمامي وشغفي لمتابعة المشروع. \\
\hline $0 ., 0$ & $r \cdot r$ & علي حسب أهميةً موضوع المشرو ع بالنسبة لي. \\
\hline Y1,0 & $\Lambda 7$ & اشعر بضيق وملل ويجعلني انصرف عن مشاهدة البرنامج. \\
\hline $1 \cdots$ & $\varepsilon \cdots$ & المجموع \\
\hline
\end{tabular}

$$
\text { جدول رقم (ד) }
$$

توزيع عينة الار اسة وفقا لمدي تأثير أساليب الإقناع بالبرامج الحوارية في تغير التجاههم نحو مشاريع التنمية

\begin{tabular}{|c|c|c|}
\hline النسبة & 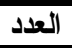 & مدي تأثير أساليب الإقناع \\
\hline OV,YO & rrq & تغير ر أيكك إذا أقنعك البرنامج بوجهة نظر أخري \\
\hline$\varepsilon Y, \vee O$ & $|V|$ & تتمسك بر أيك مهما كانت صحة ما ورد في البرنامج \\
\hline $1 \cdots$ & $\varepsilon \cdots$ & الإجمالي \\
\hline
\end{tabular}

جدول رقم (v)

اختبار (ت) لمعنوية الاختلاف بين منخفضي التعرض وكثيفي التعرض لأساليب الإقتاع

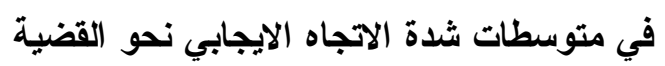

\begin{tabular}{|c|c|c|c|c|c|c|c|}
\hline الدلالة & الحرجة & قيمة ت & معامل & الالمعراف اف & المتوسط & العدد & حجم التعرض لأساليب الإقناع \\
\hline \multirow{2}{*}{$\cdot, \ldots$} & \multirow{2}{*}{ rדז } & \multirow{2}{*}{$0,0 \leq 7$} & $\cdot, 1 \cdot 1$ & $r, I \leqslant \wedge$ & $r \cdot, 10$ & vo & منخفض \\
\hline & & &., 01 & $r, \varepsilon \cdot 1$ & 1, & 19. & مرتفع \\
\hline
\end{tabular}

جدول رقم (^)

اختبار ( ت) لمعنوية الفروق بين منخفضي ومرتفعي الوعي السياسى من حيث متوسطات شدة الاتجاه نحو القضية .

\begin{tabular}{|c|c|c|c|c|c|c|c|}
\hline الدالاة & الدرجية & قيمة ت & الخطأ & الالمعراف افي & المتوسط & العدد & السياسي \\
\hline \multirow{2}{*}{$\cdot, \cdots$} & \multirow{2}{*}{ rAl } & \multirow{2}{*}{$\varepsilon$, Tor } & $\cdot, \cdot \vee \cdot$ & $\cdot, 7 r 9$ & TY,rV & $11 \% 0$ & منخفض \\
\hline & & & $\cdot, .70$ & $\cdot, \leqslant \vee 1$ & $r q, \leqslant 0$ & $1 \leqslant \wedge$ & مرتفع \\
\hline
\end{tabular}

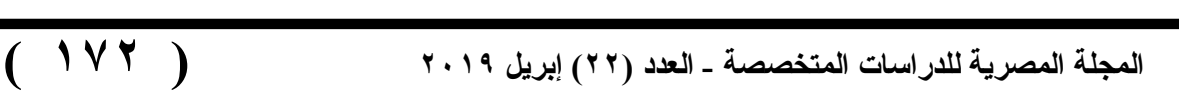


دور أساليب الإقناع بالبرامج الحوارية فى تثكيل اتجاهات الرأى العام نحو مشروعات التنمية

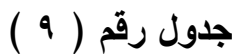

اختبار ( ت) لمعنوية الفروق بين منخفضي ومرتفعي مستوي مألوفية القضية من حيث متوسطات شدة الاتجاه نحو مشاريع التنمية .

\begin{tabular}{|c|c|c|c|c|c|c|c|}
\hline الالالة & الحرية & قيمة ت & معامل & المعياري & المتوسط & العدد & القضية \\
\hline \multirow{2}{*}{$\cdot, \cdots$} & \multirow{2}{*}{ r7q } & \multirow{2}{*}{$\Lambda, Y \backslash \wedge$} & $\cdot, 1 \leqslant r$ & $\cdot, \vee>0$ & 19,71 & ITr & منخفض \\
\hline & & & $\cdot, \leqslant \circ V$ & $\cdot, 7 \wedge$ & $r T, r V$ & $1 \leqslant 1$ & مرتفع \\
\hline
\end{tabular}

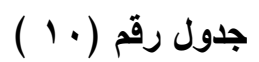

اختبار ( ت) لمعنوية الفروق بين منخفضي ومرتفعي مستوي الانغماس من حيث

متوسطات شدة الاتجاه نحو مشاريع التنمية

\begin{tabular}{|c|c|c|c|c|c|c|c|}
\hline الالالة & الحرية & قيمة ت & معامل & المعيار (الحي & المتوسط & العدد & مستوب \\
\hline \multirow{2}{*}{$\cdot, \cdots$} & \multirow{2}{*}{ r^q } & \multirow{2}{*}{$11, Y \wedge 1$} & $\cdot, \cdot V V$ & •, T0 & $r r, \wedge q$ & 11. & منخفض \\
\hline & & & $\cdot, \Sigma \wedge$ & $.0 Y 1$ & $r \cdot, r)$ & 111 & مرتفع \\
\hline
\end{tabular}

جدول رقم (11 ) - (11) - (1)

اختبار ( ت) لمعنوية الفروق بين منخفضي ومرتفعي درجة إعمال العقل من حيث

متوسطات شدة الاتجاه نحو مشاريع التنمية لئن

\begin{tabular}{|c|c|c|c|c|c|c|c|}
\hline الدلالة & الدرجة & قيمة ت & الخطأ & الالمعر اف & المتوسط & العدد & إعلعال \\
\hline \multirow{2}{*}{ r., } & \multirow{2}{*}{$r \wedge \varepsilon$} & \multirow{2}{*}{$r, 9 \wedge \leq$} & $\cdot, \cdot \leq 9$ & $\Upsilon, \uparrow \wedge \varepsilon$ & $r \leq, r V$ & 11. & منخفض \\
\hline & & & $\cdot, 1 \leqslant 0$ & $Y, 071$ & TY,YA & 187 & مرتفع \\
\hline
\end{tabular}

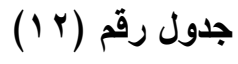

اختبار ( ت) لمعنوية الفروق بين منخفضي ومرتفعي مستوي التعليم من حيث

\begin{tabular}{|c|c|c|c|c|c|c|c|}
\hline الدلالة & الحرية & قيمة ت & معامل & الالمعريار افي & المتوسط & العدد & التعليم \\
\hline \multirow{2}{*}{., 07} & \multirow{2}{*}{ TAV } & \multirow{2}{*}{., .01} & $\cdot, 11$ & $r, \wedge q$ & $r q, \leqslant \wedge$ & ITr & منخفض \\
\hline & & & $\cdot, Y \wedge$ & $\varepsilon, 0 \wedge$ & $Y \wedge, Y \leq$ & 107 & مرتفع \\
\hline
\end{tabular}

متوسطات شدة الاتجاه نحو مشاريع التنمية

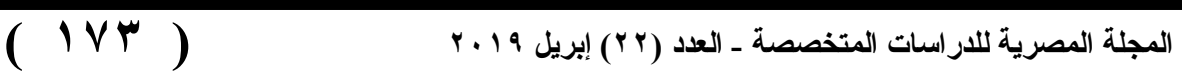


(الثيماء رضا حبره

\begin{tabular}{|c|c|c|c|c|c|c|c|}
\hline طات شدة & 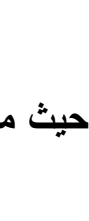 & . & يع التت & نحفو مثي & روق بير & L & ختبار ( د \\
\hline الدلالة & الدرجية & قيمة & الخطأ & الالاحيراف & المتوسط & العدد & العمر \\
\hline \multirow{2}{*}{$\cdot, .9$} & \multirow[t]{2}{*}{$r . q$} & \multirow{2}{*}{$1, \wedge 7$} & $\cdot, \Lambda$ & $\varepsilon, Y \wedge$ & $r_{0, \cdot T}$ & $\Lambda \Lambda$ & منخفض \\
\hline & & & 1,07 & $r, 09$ & YT,QT & 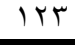 & مرتفع \\
\hline
\end{tabular}

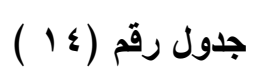

اختبار ( ت) لمغنوية الفروق بين النوع من حيث متوسطات شدة الاتجاه نحو القضية

\begin{tabular}{|c|c|c|c|c|c|c|c|}
\hline الدلالة & الحرية & قيمة ت & الخطاً & الالمعر اف & المتوسط & العدد & النوع \\
\hline \multirow{2}{*}{$\cdot, V Y Y$} & \multirow{2}{*}{$r q \Lambda$} & \multirow{2}{*}{$1, \leqslant 0 r$} & $\cdot, \cdot V$ & $r, 071$ & $r\urcorner, V \leq$ & 199 & ذكور \\
\hline & & & $\cdot, 0 \mathrm{~V}$ & $r, 109$ & Y0,9T & $r \cdot 1$ & إناث \\
\hline
\end{tabular}

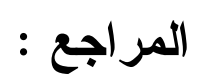

1 ـ بعزيز إبر اهيم ، التضليل الإعلامسي : كيف يقوم الإعلام بتسطيح ثقافة الجمـاهير

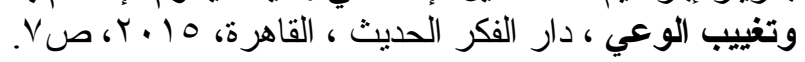

2- Trevor Diehl, Brian E Weeks ,Homero Gil de Zuniga, political persuasion on social media : tracing direct and indirect effects of news use and social interaction, new media\& society 2016 Vol18,N9,pp 1875:1895.

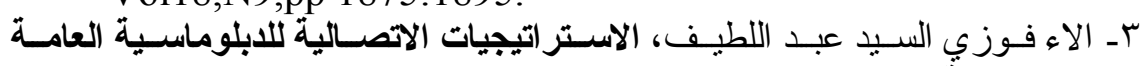

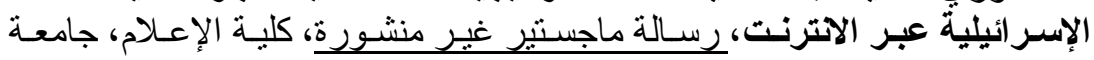

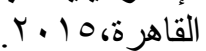

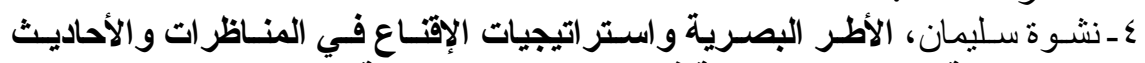

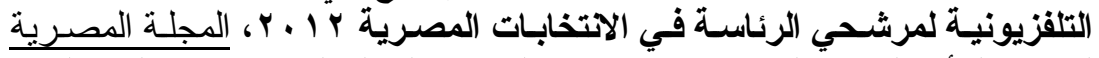

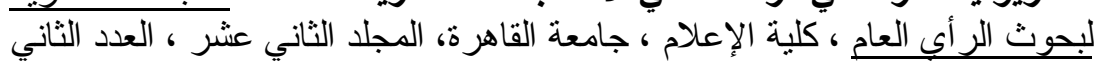

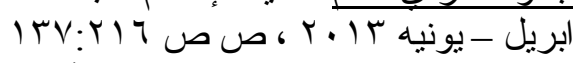

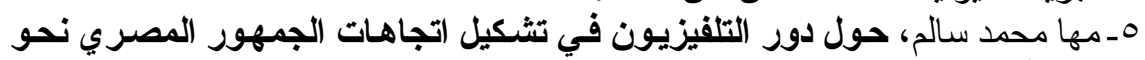

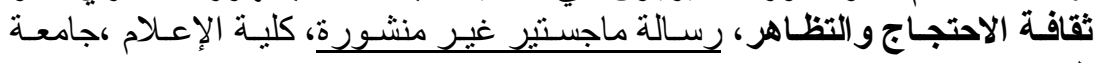


7ـ علي عباس فياض ،دور القتوات الإخبارية العربية في تثكيل اتجاهات الرأي العام

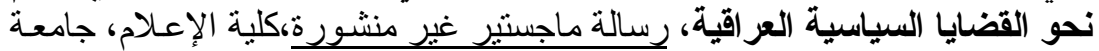

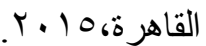

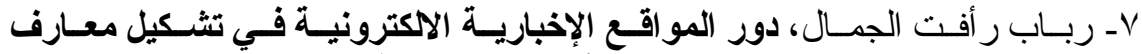

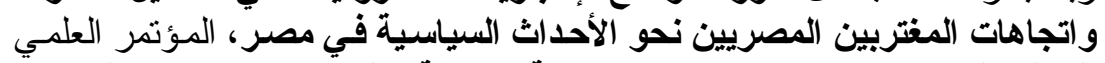

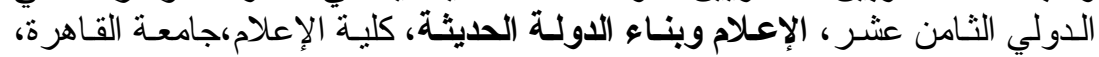

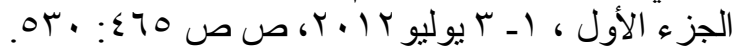

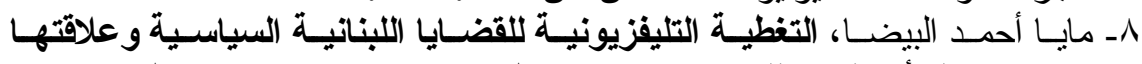

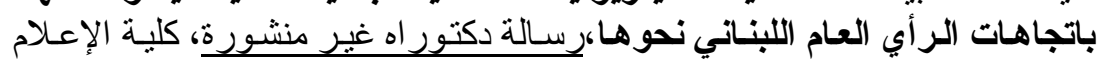

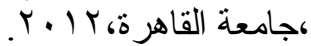

9- Xiaoxia Cao. Hearing it from jon stewart: the impact of daily show on public attentiveness to politics, International Journal of Public Opinion Research , Vol.22, No1, 2010. pp26:46

• اـ علي فرجاني، العلاقتات العامـة واستراتيجيات الاتصـال، طا ، الأردن، دار امجد

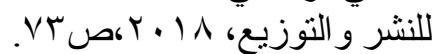

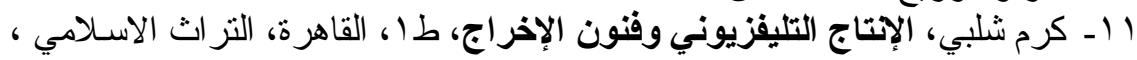
r.

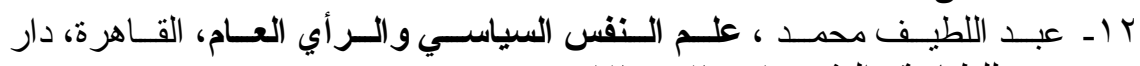

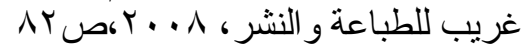

